Research, Society and Development, v. 9, n. 11, e609119537, 2020

(CC BY 4.0) | ISSN 2525-3409 | DOI: http://dx.doi.org/10.33448/rsd-v9i11.9537

Methods to detect fungi in seeds of the Austronium graveolens, Bauhinia forficata and Cordia trichotoma (Vell.)

Métodos de detecção de fungos em sementes de Austronium graveolens, Bauhinia forficata e Cordia trichotoma (Vell.)

Métodos de detección de hongos en semillas de Austronium graveolens, Bauhinia forficata y Cordia trichotoma (Vell.)

Received: 10/22/2020 | Reviewed: 10/29/2020 | Accept: 10/30/2020 | Published: 11/04/2020

\title{
Caliandra Bernardi
}

ORCID: https://orcid.org/0000-0002-2584-175X Universidade Tecnológica Federal do Paraná, Brasil E-mail: caliandra.bernardi@ hotmail.com Maristela dos Santos Rey

ORCID: https://orcid.org/ 0000-0002-9323-0395 Universidade Tecnológica Federal do Paraná, Brasil E-mail: maris_rey@yahoo.com.br Américo Wagner Júnior

ORCID: https://orcid.org/0000-0001-5081-5281 Universidade Tecnológica Federal do Paraná, Brasil E-mail: americowagner@hotmail.com João Henrique Pietrobom

ORCID: https://orcid.org/ 0000-0002-3023-6765 Universidade Tecnológica Federal do Paraná, Brasil E-mail: jhpietrobom@gmail.com

\begin{abstract}
The importance of native forest seeds, free of phytopathogens, is a strategy for the implantation of quality forest plantations. The scarcity of information about the health conditions of seeds of native forest species causes the spread of diseases. The objective of this work was to determine a method of sanitary analysis to identify pathogens in seeds of the species of Austronium graveolens, Bauhinia forficata and Cordia trichotoma (Vell.). The treatments consisted of filter paper methods with and without disinfestation in the periods of seven and 15 days, 15 days with water restriction, with BDA medium by seven and 15 days
\end{abstract}


and BDA medium with water restriction during 15 days. For each test, it was used 400 seeds. The results showed that for each forest specie seeds the best detection method was in a Petri dish with culture medium and seed disinfestation, the Austronium graveolens and Bauhinia forficata seeds need an incubation period of 15 days with water restriction and Cordia trichotoma (Vell.) seeds of seven days.

Keywords: Pathogens; Health; Analizes.

\section{Resumo}

A importância de sementes florestais nativas, isenta de fitopatógenos, é uma estratégia para a implantação de plantios florestais com qualidade. A escassez de informações acerca das condições sanitárias das sementes de espécies florestais nativas faz com que ocorra disseminação de doenças. Diante disso, o objetivo deste trabalho foi determinar um método de análise sanitária para identificação de patógenos em sementes das espécies de Guaritá, Pata de Vaca e Louro pardo. Os tratamentos consistiram nos métodos de papel filtro com e sem desinfestação, nos períodos de sete e quinze dias, e quinze dias com restrição hídrica, e meio BDA com 7 e 15 dias e meio BDA com restrição hídrica, por 15 dias. Para cada teste utilizouse um lote de 400 sementes. Os resultados demonstraram que o melhor método de detecção para as espécies foi Placa de petri com meio de cultura e desinfestação das sementes, sendo Guaritá e Pata de Vaca, necessário um período de incubação de quinze dias, com restrição hídrica e Louro pardo, sete dias.

Palavras-chave: Patógenos; Sanidade; Análises.

\section{Resumen}

La importancia de las semillas forestales nativas, libres de fitopatógenos, es una estrategia para plantaciones forestales de calidad. La escasez de información sobre las condiciones sanitarias de las semillas de especies forestales nativas provoca la diseminación de enfermedades. El objetivo de este trabajo fue determinar un método de análisis sanitaria para identificar patógenos en semillas de las especies de Austronium graveolens, Bauhinia forficata y Cordia trichotoma (Vell.). Los tratamientos consistieron en métodos de papel de filtro con y sin desinfestación en los períodos de siete y quince días, quince días con restricción del agua, con medio BDA a los siete y quince días y medio BDA con restricción de agua durante quince días. Para cada prueba se utilizaron 400 semillas. Los resultados mostraron que para cada semilla de especie forestal el mejor método de detección fue en placa Petri con medio de cultivo y con uso de la desinfestación de semillas. Para las semillas de 
Austronium graveolens y Bauhinia forficata es necesario período de incubación de quince días con restricción del agua y para Cordia trichotoma (Vell.) se debe incubar por siete días.

Palabras clave: Patógenos; Sanidad; Análises.

\section{Introduction}

The demand for seeds of native species is the result of the need to conserve tropical forests, since they are essential in ecosystem recovery and conservation programs (Carvalho, et al., 2006).

Forest species such as the Austronium graveolens, Bauhinia forficata and Cordia trichotoma (Vell.) Arráb. ex Steud are native and they present wide geographical distribution, with various uses, such as medicinal attributes, civil construction, furniture quality and ornamentation (Cassimiro, et al., 2015, Araújo, et al., 2014, Martins, et al., 2013, Silva, et al., 2016).

In order to obtain quality seedlings is necessary that the seeds have a good genetic and phytosanitary characteristic. The genetic factor needs of evaluations to select, but the phytosanitary characteristic is dependent of the cultural practices. The phytosanitary aspect causes preoccupation because the seed present ability to mobilize over great distances, what it can become a disseminator, mainly of fungi, in places where there is no occurrence of diseases (Schultz, et al., 2015). In addition, the sanitary quality of seeds is one of the most important factors that affect the development of forest crops, due to the microorganisms can cause deterioration in the seeds, as well as subsequent lesions and abnormalities in seedlings, what later difficulty in the implantation of forest stands (Piveta, et al., 2010).

Studies regarding the correct identification of fungi and other pathogens in seeds of native forest species are scarce, but they are necessary. Because of this, this work aimed to obtain the best methods to detect fungi in the Austronium graveolens, Bauhinia forficata and Cordia trichotoma (Vell.) seeds.

\section{Methodology}

The study was carried out at the Laboratório de Fitopatologia, da Universidade Tecnológica Federal do Paraná - Câmpus Dois Vizinhos, Paraná State, Brazil, in the first semester of 2019. The seeds were collected in the year 2018 in forest arrays located at Campo Mourão city- Paraná State, Brazil. 
Research, Society and Development, v. 9, n. 11, e609119537, 2020

(CC BY 4.0) | ISSN 2525-3409 | DOI: http://dx.doi.org/10.33448/rsd-v9i11.9537

The seeds were collected according to the physiological maturation characteristics of the species with basis in the higher percentage of germination and vigor. Seeds were collected and afterthey were stored in a cold chamber for 20 days.

Stock were divided, with groups of 400 seeds for submitted the detection methods and incubation time (Table 1).

Table 1 - Detection methods, times and pre-treatments used in the tests.

\begin{tabular}{l|c|c|c|c}
\hline \multicolumn{1}{c}{ Detection methods } & \multicolumn{1}{c}{ BDA } \\
\hline \multirow{2}{*}{ Incubation time * } \\
\hline Without disinfestation & 7 & 15 & 7 & 15 \\
With disinfestation & 7 & 15 & & \\
\cline { 2 - 5 } \begin{tabular}{l} 
Water restriction \\
\cline { 2 - 5 }
\end{tabular} & & 15 & & 15 \\
\hline
\end{tabular}

* In days. Source: Authors (2020).

For the blotter test without disinfestation, in the two lots ( 7 and 15 days of incubation) the seeds were placed in Gerbox boxes with lid. Each box consisted of a repetition with 25 seeds, it being organized with three sheets of filter paper moistened with $7 \mathrm{~mL}$ of sterile water, each (Brasil, 2009). In the same method, but with disinfestation, in the two lots (7 and 15 days of incubation), a pre-treatment of the seeds was used before the assembly of the test, which consisted of immersing them in a sodium hypochlorite solution at $1 \%$ for one minute, afterwards, placed on absorbent paper to dry during 12 hours.

Subsequently, the seeds were placed in Gerbox boxes with a lid, where the batch of 400 seeds was divided into 16 boxes with twenty-five seeds, each. After their disposal, the paper was weighed, and the total in grams was multiplied by 2.5 , obtaining the total in milliliters of sterile water, used to moisten the paper.

For the method of sanitation in culture medium, in both tests ( 7 and 15 days), the seeds were previously treated with sodium hypochlorite at $1 \%$ for one minute and placed on absorbent paper to dry. After treatment, the seeds were placed in Petri dishes with BDA medium (Potato - Dextrose - Agar).

Finally, in tests with water restriction, the seeds were distributed in two tests, blotter test and BDA medium to the level of $-1 \mathrm{Mpa} \mathrm{NaCl}$ (1.72g 150mL-1) (Rey, et al., 2005). For the blotter test, the filter paper used in the Gerbox boxes was weighed and moistened the paper with same rule as in the previous test was used. For the BDA medium, the $\mathrm{NaCl}$ 
concentration was homogenized with the culture medium during preparation (Rey et al, 2008).

After, the treatments were stored in a BOD-type germinator for specific periods ( 7 and 15 days), under temperature conditions at $25^{\circ} \mathrm{C}$ and a photoperiod of 12 hours. Subsequently, the seeds were evaluated with the aid of a stereoscopic microscope, in order to identify the pathogens present, with basis on the evaluation of their development and reproduction structures (mycelium and spores). The entire microflora incident in the tests was evaluated by observation of morphology of their structures and characteristic aspects of their colonies (Bernardi \& Rey, 2020, Pereira et al., 2018).

The data obtained were submitted to statistical analysis with the Kruskal-Wallis nonparametric test $(\mathrm{p}<0.05)$, to verify whether there were statistical differences between the groups evaluated - fungi incidence.

The statistical test justifies its used, since the data in this study did not have the assumptions of the mathematical model in the parametric field of the completely randomized experimental design (normality of the data and/or homogeneity of the variance of the treatments), even when submitted to transformations by the Sasm-Agri program.

\section{Results and Discussion}

The fungus present highest incidence in the detection methods tested with the species of Austronium graveolens (Table 2), Bauhinia forficata (Table 3) and Cordia trichotoma (Vell.) (Table 4) was Fusarium sp. This pathogen causes damage in the germination of forest seeds, both in pre and post-emergence (Machado, 1988).

For the Austronium graveolens (Table 2), the genus Rhizopus presented a higher incidence than the other fungi among all tests used, with an average of $83 \%$ of infestation. The Bauhinia forficata showed a similar incidence of fungi Fusarium sp. (18\%), Penicillium sp. (15\%) and Rhizopus sp. (14.5\%) in the evaluated seeds| (Table 3). The Cordia trichotoma (Vell.) showed $100 \%$ of the seeds infested with Rhizopus sp., Fusarium sp. and Chaetomium sp (Table 4). 
Research, Society and Development, v. 9, n. 11, e609119537, 2020

(CC BY 4.0) | ISSN 2525-3409 | DOI: http://dx.doi.org/10.33448/rsd-v9i11.9537

Table 2. Fungi incidence (\%) for A. graveolens seeds according detection method.

\begin{tabular}{|c|c|c|c|c|c|c|c|c|}
\hline \multirow{3}{*}{ Fungi } & \multicolumn{8}{|c|}{ Detection Methods } \\
\hline & \multicolumn{5}{|c|}{ Blotter test } & \multicolumn{3}{|c|}{ Dish Petri® } \\
\hline & $\begin{array}{l}7 \text { days } \\
\text { S/D* }\end{array}$ & $\begin{array}{l}15 \text { days } \\
\text { S/D }\end{array}$ & $\begin{array}{l}7 \text { days } \\
\text { C/D** }\end{array}$ & $\begin{array}{l}15 \text { days } \\
\text { C/D }\end{array}$ & $\begin{array}{l}15 \text { days } \\
\mathrm{RH}^{* * *}\end{array}$ & \begin{tabular}{|l|}
7 days \\
C/D \\
\end{tabular} & $\begin{array}{l}15 \text { days } \\
\text { C/D }\end{array}$ & $\begin{array}{l}15 \text { days } \\
\mathrm{RH}\end{array}$ \\
\hline Alternaria sp. & - & - & - & - & $25 \mathrm{a}$ & - & - & - \\
\hline Aspergillus sp. & $18 a b$ & $2 a b$ & $10 a b$ & $12 a b$ & - & $3 \mathrm{a}$ & $7 \mathrm{a}$ & $6 \mathrm{ab}$ \\
\hline Aspergillus niger & - & - & $1 \mathrm{a}$ & $1 \mathrm{a}$ & - & $1 \mathrm{a}$ & - & $2 \mathrm{ab}$ \\
\hline Botrytis sp. & - & - & - & - & $1 \mathrm{a}$ & - & - & $1 \mathrm{a}$ \\
\hline Cylindrocladium sp. & - & - & - & - & - & $9 \mathrm{a}$ & $1 \mathrm{a}$ & $5 \mathrm{ab}$ \\
\hline Cladosporium sp. & - & $2 a b$ & $3 \mathrm{a}$ & $3 a b$ & - & - & - & - \\
\hline Colletotrichum sp. & - & - & - & - & - & $3 \mathrm{a}$ & $34 \mathrm{ab}$ & $46 \mathrm{bc}$ \\
\hline Fusarium sp. & $\begin{array}{l}55,5 \\
\mathrm{bc}\end{array}$ & $51 \mathrm{~cd}$ & $23 \mathrm{~b}$ & $23 \mathrm{bc}$ & $71 \mathrm{ab}$ & $16 \mathrm{a}$ & $9 \mathrm{a}$ & $33 a b c$ \\
\hline Mucor sp. & - & $3 \mathrm{abc}$ & - & - & - & - & - & - \\
\hline Penicillium sp. & $\begin{array}{l}18,5 \\
a b\end{array}$ & - & $5 \mathrm{ab}$ & $5 \mathrm{ab}$ & - & - & - & - \\
\hline Phomopsis sp. & - & - & - & - & - & - & - & - \\
\hline Rhizoctonia sp. & - & $30 \mathrm{bcd}$ & - & - & $1 \mathrm{a}$ & $31 \mathrm{ab}$ & $3 \mathrm{a}$ & $2 a b$ \\
\hline Rhizopus sp. & $100 \mathrm{c}$ & $70 \mathrm{~d}$ & $35 \mathrm{ab}$ & $59,5 \mathrm{c}$ & $100 \mathrm{~b}$ & $100 \mathrm{~b}$ & $99 \mathrm{~b}$ & $100 \mathrm{c}$ \\
\hline Stemphylium sp. & - & - & - & - & - & - & $5 \mathrm{a}$ & - \\
\hline Trichoderma sp. & $0,5 \mathrm{a}$ & - & - & - & & $1 \mathrm{a}$ & $14 \mathrm{a}$ & - \\
\hline
\end{tabular}

Percentage of incidence followed by lowercase letters in the column differ from each other, at the level of $5 \%$ probability, by the Kruskal-Wallis test, at the level of $5 \%$ probability. S / D * = No disinfestation, $\mathrm{C} / \mathrm{D} * *=$ With $1 \% \mathrm{NaOCl}$ disinfestation, $\mathrm{R} . \mathrm{H} * * *=\mathrm{NaCl}$ Water Restriction. Source: Authors (2020).

The Table 2 showed the incubation methods used in this study and the fungi detected in each one, with its respective percentage of incidence. It was noted that there are differences between the methods used, according to the incidence of each fungus.

In all species evaluated, the genus Fusarium was detected. According to Cicarelli Netto et al. (2003), evaluated the physiological and health quality of native seeds, observed that the incidence of Fusarium sp. can cause damage in the seedlings produced.

Fantinel et al. (2013) reported that Fusarium sp. is a fungus commonly found in forest seeds. This microorganism, in the vast majority of its species is responsible for seed deterioration (Maciel, et al., 2012) and damping-off (Lazarotto, et. al. 2012), requiring pathogenicity tests to verify transmission and severity of the same plants (Benetti et al. 2009). The pathogen is easily identified during the tests, due to its high rate of mycelial growth and easily identified characteristics, such as densified hyphae, which may have a white to violet color, facilitating its detection in the tests (Leslie \& Summerell, 2006).

The other microorganisms detected, had an incidence below $8 \%$, when compared to all 
detection tests (Tables 2, 3 and 4).

Table 3. Fungi incidence for B. forficata seeds according detection method.

\begin{tabular}{|c|c|c|c|c|c|c|c|c|}
\hline \multirow[t]{3}{*}{ Fungi } & \multicolumn{8}{|c|}{ Detection Methods } \\
\hline & \multicolumn{5}{|c|}{ Blotter test } & \multicolumn{3}{|c|}{ Dish Petri® } \\
\hline & $\begin{array}{l}7 \text { days } \\
\text { S/D* }\end{array}$ & $\begin{array}{c}15 \text { days } \\
\text { S/D }\end{array}$ & $\begin{array}{l}7 \text { days } \\
\mathrm{C} / \mathrm{D} * *\end{array}$ & $\begin{array}{c}15 \text { days } \\
\text { C/D }\end{array}$ & $\begin{array}{l}15 \text { days } \\
\mathrm{RH}^{* * *}\end{array}$ & $\begin{array}{c}7 \text { days } \\
\text { C/D }\end{array}$ & $\begin{array}{c}15 \text { days } \\
\text { C/D }\end{array}$ & $\begin{array}{c}15 \text { days } \\
\mathrm{RH}\end{array}$ \\
\hline Alternaria sp. & $2,5 \mathrm{ab}$ & - & - & $7 \mathrm{ab}$ & $4 \mathrm{a}$ & - & - & - \\
\hline Aspergillus sp. & $0,5 \mathrm{a}$ & - & - & $5 \mathrm{ab}$ & $8 \mathrm{ab}$ & $1 \mathrm{a}$ & $4 \mathrm{a}$ & $3 a b$ \\
\hline Aspergillus niger & - & - & - & - & $1 \mathrm{a}$ & - & - & $10 \mathrm{ab}$ \\
\hline Bipolaris sp. & - & - & - & - & - & - & $0,5 \mathrm{a}$ & $3 a b$ \\
\hline Botrytis sp. & - & - & $1,5 \mathrm{a}$ & $1 \mathrm{a}$ & $2 \mathrm{a}$ & $7 \mathrm{ab}$ & - & $5 \mathrm{ab}$ \\
\hline Chaetomium sp. & - & $0,5 \mathrm{a}$ & - & - & $4 \mathrm{ab}$ & $1 \mathrm{a}$ & - & - \\
\hline Cylindrocladium sp. & - & - & - & - & - & - & - & $4 a b$ \\
\hline Cladosporium sp. & $2 a b$ & $4 \mathrm{ab}$ & $3 \mathrm{a}$ & - & $2 \mathrm{a}$ & - & $2 \mathrm{a}$ & $9 \mathrm{ab}$ \\
\hline Colletotrichum sp. & - & - & - & - & - & - & - & $22 \mathrm{bb}$ \\
\hline Fusarium sp. & $12,5 \mathrm{~b}$ & $3,5 \mathrm{a}$ & $17 \mathrm{~b}$ & $17 a b$ & $72 b$ & $3 a b$ & $7,5 \mathrm{a}$ & $13 \mathrm{ab}$ \\
\hline Giberella sp. & - & - & - & $1 \mathrm{a}$ & - & - & - & - \\
\hline Penicillium sp. & $2 \mathrm{a}$ & $41,5 \mathrm{~b}$ & $8 \mathrm{ab}$ & $26 \mathrm{~b}$ & $2 \mathrm{a}$ & $19 \mathrm{~b}$ & 9 a & $13 a b$ \\
\hline Pestalotia sp. & - & - & - & - & - & - & - & $2 \mathrm{ab}$ \\
\hline Phomopsis sp. & - & - & - & 1 & $3 \mathrm{a}$ & - & - & - \\
\hline Rhizoctonia sp. & - & $8 \mathrm{ab}$ & - & $1 \mathrm{a}$ & $13 \mathrm{ab}$ & $11 \mathrm{ab}$ & $5 \mathrm{a}$ & $1 \mathrm{a}$ \\
\hline Rhizopus sp. & $15 \mathrm{ab}$ & $3 \mathrm{a}$ & $8 \mathrm{a}$ & $33 \mathrm{~b}$ & $27 \mathrm{ab}$ & - & - & $30 a b$ \\
\hline Stemphylium sp. & - & $1 \mathrm{a}$ & - & - & - & - & - & - \\
\hline Verticillium sp. & - & - & - & - & - & $2 a b$ & - & - \\
\hline
\end{tabular}

Percentage of incidence followed by lowercase letters in the column differ from each other, at the level of $5 \%$ probability, by the Kruskal-Wallis test, at the level of $5 \%$ probability. S / D * = No disinfestation, $\mathrm{C} / \mathrm{D} * *=$ With $1 \% \mathrm{NaOCl}$ disinfestation, $\mathrm{R} . \mathrm{H} * * *=\mathrm{NaCl}$ Water Restriction. Source: Authors (2020).

In Tables 3 and 4 is important to observe the increase in the number of genera of fungi incident on the seeds of $B$. forficata and $C$. trichotoma with use of different detection methods. 
Research, Society and Development, v. 9, n. 11, e609119537, 2020

(CC BY 4.0) | ISSN 2525-3409 | DOI: http://dx.doi.org/10.33448/rsd-v9i11.9537

Table 4. Fungi incidence for $C$. trichotoma seeds according detection method.

\begin{tabular}{|c|c|c|c|c|c|c|c|c|}
\hline & \multicolumn{8}{|c|}{ Detection Methods } \\
\hline & \multicolumn{5}{|c|}{ Blotter test } & \multicolumn{3}{|c|}{ Dish Petri® } \\
\hline & $\begin{array}{l}7 \text { day } \\
\text { S/D* }\end{array}$ & $\begin{array}{c}15 \text { day } \\
\text { S/D }\end{array}$ & $\begin{array}{c}7 \text { day } \\
\text { C/D** }\end{array}$ & $\begin{array}{c}15 \text { day } \\
\text { C/D }\end{array}$ & $\begin{array}{l}15 \text { day } \\
\mathrm{RH}^{* * *} *\end{array}$ & $\begin{array}{c}7 \text { day } \\
\text { C/D }\end{array}$ & $\begin{array}{c}15 \text { day } \\
\text { C/D }\end{array}$ & $\begin{array}{c}15 \text { day } \\
\mathrm{RH}\end{array}$ \\
\hline Alternaria sp. & $45 \mathrm{~cd}$ & $100 \mathrm{~b}$ & $40 \mathrm{bc}$ & $40 \mathrm{~b}$ & $24 \mathrm{~b}$ & - & $2 \mathrm{a}$ & - \\
\hline Aspergillus sp. & $1 \mathrm{a}$ & - & $9 a b$ & $6 \mathrm{a}$ & $4 \mathrm{a}$ & $21 \mathrm{ab}$ & - & $5 \mathrm{a}$ \\
\hline Aspergillus niger & - & - & - & - & - & $1 \mathrm{a}$ & - & - \\
\hline Bipolaris sp. & - & - & - & - & - & - & $6 \mathrm{a}$ & - \\
\hline Botrytis sp. & $20 \mathrm{bcd}$ & $1 \mathrm{a}$ & $15 a b$ & $33 \mathrm{ab}$ & $11,5 \mathrm{ab}$ & $7 \mathrm{a}$ & $6 \mathrm{a}$ & $3 \mathrm{a}$ \\
\hline Chaetomium sp. & - & - & - & - & - & $100 \mathrm{c}$ & - & - \\
\hline Cylindrocladium sp. & - & - & - & - & - & - & $7 \mathrm{a}$ & - \\
\hline Cladosporium sp. & $6 \mathrm{abc}$ & $1 \mathrm{a}$ & - & - & - & - & $13 \mathrm{a}$ & $6 \mathrm{a}$ \\
\hline Colletotrichum sp. & - & - & - & - & - & $5 \mathrm{a}$ & $37 \mathrm{a}$ & $22 \mathrm{a}$ \\
\hline Fusarium sp. & $100 \mathrm{~d}$ & $100 \mathrm{~b}$ & $100 \mathrm{c}$ & $100 \mathrm{~b}$ & $100 \mathrm{~b}$ & $50 \mathrm{bc}$ & $52 \mathrm{a}$ & $21 \mathrm{ab}$ \\
\hline Penicillium sp. & $5 \mathrm{ab}$ & - & $17 \mathrm{abc}$ & $4 \mathrm{a}$ & $2,5 \mathrm{a}$ & $2 \mathrm{a}$ & $3 \mathrm{a}$ & $4 \mathrm{a}$ \\
\hline Rhizoctonia sp. & - & - & - & - & $1 \mathrm{a}$ & - & $7 \mathrm{a}$ & $10 \mathrm{a}$ \\
\hline Rhizopus sp. & - & - & $1 \mathrm{a}$ & - & - & - & $20 \mathrm{a}$ & $100 \mathrm{~b}$ \\
\hline Stemphylium sp. & - & - & - & - & - & $15 a b$ & - & - \\
\hline Verticillium sp. & - & - & - & - & - & $4 \mathrm{a}$ & - & $1 \mathrm{a}$ \\
\hline
\end{tabular}

Percentage of incidence followed by lowercase letters in the column differ from each other, at the level of 5\% probability, by the Kruskal-Wallis test, at the level of $5 \%$ probability. S / D * = No disinfestation, $\mathrm{C} / \mathrm{D} * *=$ With $1 \% \mathrm{NaOCl}$ disinfestation, R.H $* * *=\mathrm{NaCl}$ Water Restriction. Source: Authors (2020).

The method that proved to be inappropriate for the detection of fungi in all species was the blotter test with 7 days and without disinfestation, because it was observed that it easily detected fast-growing fungi like Rhizopus sp. and Fusarium sp. and without satisfactory results in the detection of fungi with slower vegetative development and in most phytopathogens.

In this case, the lack of pre-treatment in the seeds may have facilitated the development of hyphae that prevented the incidence of other fungi. However, Mendes et al. (2011) evaluated seeds of Leucaena leucocephala (Lam.) with and without disinfestation concluded that the use of previous disinfestation in the health test effectively reduced the detection of fungi, due to some of the detected microorganisms to be saprophytes and to stay on the seed surface, what it was different of results obtained in this work.

This observation was corroborated by Rey et al. (2008), where with the water restriction technique does not alter the existing microflora and incident fungi in the seeds of Phaseolus vulgaris. In addition, when a non-toxic restrictor was used, which delays seed germination and maintain the viability, such as $\mathrm{NaCl}$, the secondary contamination was 
prevented. The same, it still facilitates the evaluation of the fungi present in the test, it does not affect the seeds, it does not lead to senescence (Parisi, et al., 2019).

Regarding the total microflora, which infested or infected the seeds (data not presented), in the Austronium graveolens seeds, in the petri dish with culture medium method, during two incubation times, there were occurrence of 8 genera. The petri dish method with 15 days and water restriction favored the incidence of 13 genera in the Bauhinia forficata seeds, and the same method, however with 15 days and with disinfestation, detected 10 genera in the Cordia trichotoma (Vell.) seeds.

In this study, when the averages of incidence were submitted to the Kruskal-Wallis test for comparison with each other, in the species of seeds studied, there was no statistical difference among the different species of fungi evaluated. However, the results showed an ease of some methods in detecting certain phytopathogenic fungi. In the Austronium graveolens seeds, when the petri dish method with BDA medium was used at different times, the fungus Cylindrocladium sp., responsible for leaf spots and necrosis in forest species (Schultz et al., 2015), was detected. The same occurred for the Bauhinia forficata and Cordia trichotoma seeds, what demonstrated the ease of incidence of the pathogen in the method. Using the same test, the fungus Colletotrichum sp., agent of anthracnosis in several forest species (Carmo, et al., 2017), was observed in the A. graveolens and B. forficata seeds. These fungi are essentially dependent on high humidity (Alfenas et al., 2009), due to this, their preference for this method, where the seeds are in direct contact with the culture medium. It was noted that the use of the water restrictor in the blotter test prevented the occurrence of fungi in the test. Due to the presence of $\mathrm{NaCl}$, there was a decrease in the absorption of available water in the paper (substrate) used, delaying germination, however, preventing the development of some fungi (Oliveira et al., 2011). However, when the same restrictor was added to the culture medium in a petri dish, with disinfestation and incubation for 15 days, there were the occurrence of genera potentially phytopathogenic, as Cylindrocladium (Austronium graveolens), Colletotrichum (Austronium graveolens and Bauhinia forficata), Bipolaris (Bauhinia forficata).

In addition to the occurrence of potentially pathogenic fungi such as Fusarium sp., (Leslie \& Summerell, 2006), the genus Rhizopus sp. was detected with medium to high incidence in the seeds. It is considered as storage pathogen and it is associated with the deterioration of seeds, with action dependent on the physical and physiological conditions (Filho, et al., 2004). Martinelli-Seneme et al. (2006) detected fungi Aspergillus sp., Cladosporium sp., Colletotrichum sp., Fusarium moliniforme, Penicillium sp., Rhizoctonia 
solani and Rhizopus stolonifer in the Bauhinia forficata seeds through blotter test with and without disinfestation by $2 \% \mathrm{NaOCl}$ during $5 \mathrm{~min}, 10 \mathrm{~min}$ and $20 \mathrm{~min}$, what it corroborated with the results of this work.

In tests for the detection of Cordia trichotoma (Vell.) seeds, the fungus Fusarium sp. was in $100 \%$ of seeds, what it demonstrated efficiency with the blotter test method for this native species. Similar results were described by Silva \& Muniz (2003), evaluated seeds of the species collected in Rio Grande do Sul State, with a high incidence of Fusarium sp.

According to Dhingra (1985), when phytopathogenic fungi are already established in the dormant mycelium inside the seeds, they can develop, even if the amount of water is less than that required for normal seed metabolism. However, easily identified characteristics of this imperfect fungus, such as densified hyphae, which it can have a white to violet color, and a high mycelial growth rate, facilitate their detection in tests (Leslie \& Summerell, 2006).

In this work, it was seen that the methods of detecting pathogens in seeds, together with the incubation time, vary among forest species. It was also noted, in agreement with data already published (Parisi, et al., 2016, Walker, et al., 2013), that fungi that are on the surface of the seeds may not cause disease and be present, only infesting them. However, they can reduce the germination or lost the viability (Costa, et al., 2016, Bernardi, et al. 2018). It was obtained that among the evaluated seeds, the method that most detected fungi, both saprophytic and phytopathogenic, was the medium in a petri dish with 15 days and water restriction (Table 2).

The interference of pathogens related to seeds can promote losses in production due to the reduction of the plant population, with increase of diseases in areas, until then, healthy. Thus, the study with fungi detected in forest seeds, frequency of incidence is important since they may provide subsidies for the production of quality seedlings.

\section{Conclusion}

The best method of detecting pathogens in seeds of each specie was a petri dish using B.D.A. Regarding the incubation time Austronium graveolens and Bauhinia forficata seeds needed 15 days with the addition of water restriction, while Cordia trichotoma (Vell.) seeds had a higher incidence at seven days, without using a water restrictor, both with disinfestation of the seeds.

The study demonstrated the importance of different methodologies used for the detection of phytopathogenic fungi in the forest pathology. The detection of fungi for each 
specie has an easy incidence in different methods used, which it implies with transmission of diseases and consequently problems in forest nurseries.

\section{References}

Alfenas, A. C., Zauza, E. A. V., Mafia, R. G., \& Assis, T. F. (2009). Clonagem e doenças do eucalipto. Viçosa: UFV. 442.

Araújo, D., Sebbenn, A. M., Zanatto, A. C. S., Zanata, M., Morais, E., Moraes, M. L. \& Freitas, M. L. M. (2014) Variação genética para caracteres silviculturais em progênies de polinização aberta de Astronium graveolens Jacq. (Anacardiaceae). Cerne, 20 (1), 61-68. http://dx.doi.org/10.1590/S0104-77602014000100008.

Benetti, S. C., Santos, A. F., \& Jaccoud Filho, D. de S. Levantamento de fungos em sementes de cedro e avaliação da patogenicidade de Fusarium sp. e Pestalotiopsis sp. Pesquisa Florestal Brasileira. Colombo. (2009); 58 (2), 79-83. doi: 10.4336/2009.pfb.58.8

Bernardi, C., Rey, M. S., Busso, C., Borin, R. C. \& Mazaro, S. M. (2018). First report of Bipolaris secalis causing disease on Jangada Brava (Heliocarpus americanus) seeds in Brazil. Plant Disease, 102 (5), 1034. https://doi.org/10.1094/PDIS-11-17-1764-PDN.

Bernardi, C., \& Rey, M. S. (2020). Análise de sanidade de sementes descomplicada. Dois Vizinhos. Recuperado de https://sites.google.com/view/fitopatologiautfprdv.

Brasil (2009). Ministério da Agricultura, Pecuária e Abastecimento. Manual de Análise Sanitária de Sementes / Ministério da Agricultura, Pecuária e Abastecimento. Secretaria de Defesa Agropecuária - Brasília: Mapa/ACS, 200 p.

Costa, J. R., J. C., Santos, A. F., Francisco, L., Silva, C. N., Tessmann, D. J. (2016). Qualidade sanitária e fisiológica, métodos de detecção de Fusarium spp. e tratamento de sementes de pupunheira. Ciência Florestal, Santa Maria: 26 (4), 1119-1131. doi: $10.5902 / 1980509825029$ 
Carneiro, J. S. (1986). Microflora associada a sementes de essências florestais. Fitopatologia Brasileira, Brasília, 11(3), 557-566.

Carvalho, L., Silva, E. A. A., Davide, A. C. (2006). Classificação de sementes florestais quanto ao comportamento no armazenamento. Revista Brasileira de Sementes, 28(2),15-25. https://doi.org/10.1590/S0101-31222006000200003 .

Cassimiro, J. C., Souza, R. S., Moraes, R. M. (2015). Trocas gasosas e injúrias foliares visíveis em plantas jovens de Astronium graveolens Jacq. fumigadas com ozônio. Hoehnea, 2 (2), 635-642. https://doi.org/10.1590/2236-8906-05/RAD/2015.

Cicarelli Netto, C. C., Kauffmann, M, Signor, P. (2003). Qualidade Fisiologica das sementes de Luehea divaricata (Mart.). In: Congresso Florestal Estadual do Rio Grande do Sul, 9, Nova Prata. Anais.

Fantinel, V. S., Oliveira, L. M., Muniz, M. F. B., Rocha, E. C. (2013). Detecção de fungos e transmissão de Alternaria alternata via sementes de ipê-amarelo, Handroanthus chrysotrichus (mart. ex dc) Mattos. Revista de Ciências Ambientais, Canoas, 7 (2): 05-14. https://doi.org/10.18316/1095.

Ferreira, F. A. (1989). Patologia florestal: principais doenças florestais no Brasil. Viçosa: Sociedade de Investigações Florestais, 570 p.

Filho, R. R. R., Santos, A. F., Medeiros, A. C. S., Filho, D. S. J. (2004). Fungos associados às sementes de cedro. Summa Phytopathologica, Botucatu, 30 (4).

Goulart, A. C. P. (1997). Fungos em sementes de soja: detecção e importância. EMBRAPA, Empresa Brasileira de Pesquisa Agropecuária, Centro de Pesquisa Agropecuária do Oeste, Ministério da Agricultura e do Abastecimento, 72. Recuperado de https://www.researchgate.net/publication/280533015_Fungos_em_sementes_de_soja_detecca o_importancia_e_controle. 
Grandis, A., Godoi, S., Lisboa, T., Martins, T. D., Meneguetti, C. S. B. (2004). Qualidade sanitária das sementes de Astronium graveolens (Guaritá). In: Simposio Brasileiro de Patologia De Sementes.

Lazarotto, M., Muniz, M. F. B., Santos, Á. F. dos. (2010). Detecção, transmissão, patogenicidade e controle químico de fungos em sementes de paineira (Ceiba speciosa). Summa Phytopathologica. Botucatu. 36(2), 134-139. doi: 10.1590/S010054052010000200005

Leslie, J. F., Summerell, B. A. (2006). The Fusarium Laboratory Manual. USA: Blackwell Publishing, 388 p.

Machado, J. C. (1988). Patologia de sementes: fundamentos e aplicações. Mec: Esal: Faepe.

Mantovani, N. C., Franco, E. T. H., Vestena, S. (2005). Regeneração in vitro de louro-pardo (Cordia trichotoma (Vellozo) Arrabida ex Steudel). Ciência Florestal, 11(2), 93-101.

Martinelli-Seneme, A., Possamai, E., Schuta, L. R., Vanzolini, S. (2006). Germinação e sanidade de sementes de Bauhinia forficata. R. Árvore, 30 (5), 719-724.

Martins, J. (2013). Efeito protetor da pata-de-vaca (Bauhinia forficata) contra diabetes mellitus induzido por aloxano em camundongos swiss. Revista Pleiade, 7 (12), 87-102.

Mendes, S. S., Mesquita, J. B., Marino, R. H. (2011). Qualidade sanitária de sementes de Leucaena leucocephala (Lam.) de Wit armazenadas em câmara fria. Natural Resources, 1(1), 5-22. https://doi.org/10.6008/ESS2237-9290.2011.001.0002.

Oliveira, C. F., Oliveira, D. C., Parisi, J. J. D., Barbedo, C. J. (2011). Deterioração de sementes de espécies brasileiras de Eugenia em função da incidência e do controle de fungos. Revista Brasileira de Sementes, 33 (3), 520-532. http://dx.doi.org/10.1590/S010131222011000300015. 
Parisi, J. J. D., Santos, A. F., Barbedo, C. J., Medina, P. F.(2019). Patologia de Sementes Florestais: Danos, Detecção e Controle, uma revisão. Summa Phytopathologica, 45(2), 129133. doi: $10.1590 / 0100-5405 / 188545$

Pereira, A. S., et al. (2018). Metodologia da pesquisa cientifica. [e-book]. Santa Maria: UAB / NTE / UFSM. Recuperado de https://www.ufsm.br/app/uploads/s ites/358/2019/02/Metodologia-da-Pesquisa-Cientifica_final.pdf.

Piveta, G., Menezes, V. O., Pedroso, D. C., Muniz, M. F. B., Blume, E., Wielewicki, A. P. (2010) Superação de dormência na qualidade de sementes e mudas: influência na produção de Senna multijuga (L. C. Rich.) Irwin. Acta Amazônica. 40 (2): 281 - 288. doi: 10.1590/S004459672010000200006

Rey, M. S., Lima, N. B., Santos, J., Farias, C. R. J., Pierobom, C. R. (2005) Crescimento micelial de raças de Colletotrichum lindemuthianum sob diferentes potenciais hídricos. Revista Bras. Agrociência, Pelotas. 11(3), 309-313. http://dx.doi.org/10.18 539/cast.v11I3.1250

Rey, M. S., Lima, N. B., Santos, J., Pierobom, C. R., Balardin, R. S. (2008). Inoculação de sementes de feijão comum (Phaseolus vulgaris) com Colletotrichum lindemuthianum usando diferentes níveis de restrição hídrica. Revista Bras. Agrociência, Pelotas. 2008, 14 (4), 112 116. http://dx.doi.org/10.18539/cast.v14i4.1974.

Sales, N. L. P. (1994). Efeito da população fúngica sobre a germinação das sementes e do desenvolvimento de ipê-amarelo (Tabebuia serrratifolia) e barbatimão (Stryphnodendron adstringens). Ciência e Prática, 18(1), 83-9.

Salgueiro, A. C. F. (2013). Composição Química e Avaliação dos Efeitos da Infusão de Bauhinia forficata em um Modelo Experimental com Eritrócitos Humanos Expostos a Elevadas Concentrações de Glicose in vitro. Anais do Salão Internacional de Ensino, Pesquisa e Extensão, 5(4). Recuperado de https://periodicos.unipampa.edu.br/in dex.php/SIEPE/issue/archive/2. 
Silva, L. T. M., Muniz, M. F. B. (2003). Qualidade sanitária de sementes e mudas de espécies florestais nativas produzidas na região de Santa Maria - RS. In: Congresso Florestal Estadual Do Rio Grande Do Sul, 9. Nova Prata.

Silva, R. F., Da Ros, C. O., Dellai, A., Grolli, A. L., Scheid, D., Viel, P. (2016). Interference of doses of copper on growth and quality of Bauhinia forficata Link, Pterogyne nitens Tul and Enterolobium contortisiliquum Vell. Seedlings. Ciência Florestal, 26 (2), 647-655, https://doi.org/10.5902/1980509822764.

Vechiato, M. H., Parisi, J. J. D. (2013). Importância da qualidade sanitária de sementes de florestais na produção de mudas. Biológico, São Paulo, 75 (1), 27-32.

Schultz, B., Sbravatti, J. J., Auer, A. C. G. Santos, A. F. (2015). Impacto da mancha foliar causada por Cylindrocladium candelabrum em plantios jovens de Eucalyptus benthamii em rio negrinho - SC. Ciência Florestal, Santa Maria, 25(2), 307-316 http://dx.doi.org/10.5902/1980509818448.

Carmo, A. L. M., Mazaratto, E. J., Eckstein, B., Santos, A. F. (2017). Associação de Fungos com Sementes de Espécies Florestais Nativas. Summa Phytopathologica, 43(3), 246-247, 2017. http:// dx.doi.org/ dx.doi.org/10.1590/0100-5405/2211.

Walker, C., Maciel, C. G., Bovolini, M., Pitorini, P., Schultz, C., Muniz, M. F. B. (2013). Transmissão e patogenicidade de Phomopsis sp. associadas às sementes de angico-vermelho (Parapiptadenia rígida Benth.). Floresta e Ambiente, Seropédica, 20(2), 216-222. http://dx.doi.org/10.4322/floram.2013.008.

\section{Percentage of contribution of each author in the manuscript}

Caliandra Bernardi $-25 \%$

Maristela dos Santos Rey $-25 \%$

Américo Wagner Júnior - 25\%

João Henrique Pietrobom - 25\% 